УДК 316.7; 327

Танчер Віктор Володимирович

доктор філософських наук, професор,

Київський національний університет культури і мистецтв,

Київ, Україна,

vtancher@gmail.com

\title{
ПОЛІКУЛЬТУРНІСТЬ СУЧАСНИХ СОЦІУМІВ: ТРЕНДИ ТА ВИКЛИКИ
}

Культурна різноманітність, полікультурні засади сучасних людських спільнот нерідко є чинниками соціальних напружень і конфліктів. На тлі процесів становлення глобальної світової культури, водночас, актуалізуються проблеми міжкультурних взаємин, співіснування різних культурних практик i ціннісних світів. Розгляду історичного шляху культурних взаємовпливів, їх етапів і засобів: від «культурної дифузії», завоювань, світових релігій i світських ідеологій, торгівлі, міграцій тощо - до світової комунікаційної мережі; аналізу моделей різнокультурних спільнот і проблем, що з ними пов'язані, «культурного громадянства» i «культурного імперіалізму», національної ідентичності, глобалізації, глокалізації, «нової племінності» у царині культурних відносин тощо; концепцій і програмних цілей «мультикультуралізму» присвячена ця стаття. Автор прагне підвести до висновку, що полікультурність сучасних соціумів може бути не тільки джерелом непорозумінь і ворожнечі, але й ресурсом соціального розвитку, основою гуманітарного прогресу людності.

Ключові слова: полікультурність, мультикультуралізм, культурна глобалізація, культурна взаємодія, культурне громадянство, національна ідентичність, транснаціональні корпорації, неотрайболізм.

Tancher Victor, Doctor of Philosophical Sciences, Professor, Kyiv National University of Culture and Arts, Kyiv, Ukraine

\section{Polyculturalism of modern socium: trends and challenges}

Cultural diversity and polycultural foundations of modern human communities often act as factors of social tensions and conflicts. The problems of intercultural relations and coexistence of different cultural practices and values are actualized simultaneously in the background of global world culture formation. The article aims to present historical path of cultural interactions, their stages and means ranging from "cultural diffusion", conquests, world religions and secular ideologies, trade, migration, etc. to world communication network; analysis of polycultural communities models and related issues, "cultural citizenship" and "cultural imperialism", national identity, globalization, glocalization, "neotribalism" in the field of cultural relations, etc.; the concepts and program objectives of "multiculturalism". The author seeks to 
conclude that polyculturalism of modern societies might be seen not only as a source of misunderstandings and hostility, but also as a resource of social development and the basis for human progress.

Keywords: polyculturalism, multyculturalism, cultural globalization, cultural interaction, cultural citizenship, national identification, neotribalizm.

Танчер Виктор Владимирович, доктор философских наук, профессор, Киевский национальный университет культуры и искусств, Киев, Украина

\section{Поликультурность современных социумов: тренды и вызовы}

Культурное разнообразие, поликультурные основы современных человеческих сообществ нередко являются факторами социальных напряжений и конфликтов. На фоне процессов становления глобальной мировой культуры, в то же время, актуализируются проблемы межкультурных взаимоотношений, сосуществования разных кльтурных практик и ценностных миров. Рассмотрению исторических путей культурных взаимовлияний, их этапов и средств: от «культурной диффузии», завоеваний, мировых религий и светских идеологий, торговли, миграции и т. д. до мировой коммуникационной сети, анализа моделей разнокультурных общностей и проблем связанных с ними «культурного гражданства» и «культурного империализма», национальной идентичности, глобализации, глокализации, неотрайболизму в сфере культурных отношений и т. п.; концепций и программных целей «мультикультурализма» посвящена эта статья. Автор стремился подвести к выводу, что поликультурность современных социумов - не только источник недоразумений и враждебности, но может стать ресурсом социального развития, фундаментом гуманитарного прогресса человечества.

Ключевые слова: поликультурность, мультикультурализм, культурная глобализация, культурное взаимодействие, культурное гражданство, национальная идентичность, транснациональные корпорации, неотрайболизм.

Вступ. Серед характеристик сучасного світу на перший план нині виступає феномен глобалізації. Людство стає єдиною функціональною системою, що має розвиватися на спільній ціннісно-нормативній основі, яка, у свою чергу, створюється новою, спільною глобальною культурою. Водночас, за умов виходу людства на постмодерний, постіндустріально-інформаційний рівень розвитку, виявляються глибокі соціально-культурні протиріччя (нерівноправність складових частин цієї системи, напруженість і конфлікти між культурами різних спільнот, зростаючий розрив між технологічною оснащеністю, якістю життя, ціннісними орієнтаціями розвинених країн і рештою людності тощо), викристалізовуються нагальні проблеми у цій царині, що потребують вивчення і розв'язання. 
Мета розвідки, що пропонується, окреслити коло питань, які підлягають аналізу, з'ясувати генезу означених процесів, напрям їх розвитку, основні характеристики, визначити форми i соціокультурні наслідки культурної глобалізації та зробити необхідні узагальнення.

Аналіз попередніх досліджень і публікацій. Мультикультуралізм і соціополітичні напруження в полікультурних суспільствах. Під терміном «мультикультуралізм» розуміється співіснування різних форм культурного життя, насамперед під кутом зору цілей і завдань соціальної і культурної політики розвинутих країн сучасного світу. Проте, коли підкреслюється «рівноправне співіснування», як це аргументують прихильники i теоретики мультикультуралізму (В. Кимлічка, С. Бехабиб, М. Вевьорка та ін.), то за цим вже стоїть певна спрямованість державної політики. Тобто підтримка культурних меншин, врахування специфічних інтересів етнічних і релігійних спільнот, забезпечення культурних потреб мігрантів тощо. Водночас, за умов небажання мігрантів асимілюватися чи акультуриватися iз населенням приймаючою країни виникають напруження і конфлікти, спалахує ксенофобія, агресивне протистояння культурних традицій, звичаїв, моделей поведінки. На тлі зростаючої просторової мобільності, ситуації безпосереднього співжиття та конкуренції різних світосприйнять та ціннісних систем загострюються різного роду конфлікти і протистояння у соціальному середовищі.

Викладення основного матеріалу. Політичні напруження, які збуджують стабільний і благополучний «західний світ» у XXI ст., й породжують сумніви у притаманних йому толерантності, політкоректності, благопристойності і т. п. та спонукають шукати рішення цих проблем в політичній площині взаємин у полікультурних соціумів. Такі конфлікти виникають, передусім, там, де за умов різнокультурного співіснування очікуються єдині соціальні стандарти «західного світу» без прийняття його культурних стандартів і зразків поведінки, намагань існувати одночасно в сучасній «соціальній даржаві» й сепаратному етнічному, традиційному суспільстві, або ж - в світському, ліберальному, відкритому суспільстві й спільноті, де існують релігійні, моральні жорсткі обмеження і приписи. Неминуче формуються загрози дезінтеграції соціуму, етнокультурного екстремізму аж до тероризму, конфесійних протистоянь, культурного розмежування різних спільнот.

Внутрішню суперечливість концепції ліберального мультикультуралізму вдало ілюструє метафора російського аналітика А. Малашенко (Московський центр Карнегі). Якщо розуміти мультикультуралізм як «сумісне проживання», то ж воно буває по-різному. Іноді, як у громадянському шлюбі, воно приносить взаємне задоволення, а іноді, як у комунальній квартирі: якщо поталанить з сусідами, то ще нічого, а якщо ні, то краще вже окремо. 
У будь-якому разі, думається, що треба відділяти витлумачення мультикультуралізму, (багатокультурність) людських спільнот як філософський (етичний підхід), як гуманістичний ракурс бачення перспектив людності, від нинішніх соціально-політичних практик в духовній сфері, культурної політики демонстрації толерування «інакшості» та фактичного домінування певного набору цінностей, що неминуче пов'язано 3 напруженнями i конфліктами в соціумах.

Серед причин і чинників соціальних напружень і конфліктів наших днів усе частіше називають різні морально-ціннісні орієнтації, несумісні типи світобачення, способи життя, традиції, уподобання усе те, що формується в площині певної культури і виявляється при зустрічі, взаємодії різних культур. За сучасної доби «культурна приналежність» виступає визначальним фактором людської характеристики, заступаючи нерідко місце національній, класовій, ідеологічній ідентифікації особистості.

Полікультурність $і$ «культурне громадянство». Мультикультуралізм як соціокультурна політика або багатокультурність як мета і сьогоденні практики розвинутих сучасних соціумів, в яких проголошується співіснування множини культур, де ніхто не домінує, натомість містить внутрішню суперечність. По-перше, в реальності виявляється, що домінує один зразок культури, який означують як «західний», американо-європейський, вказують на «культурний імперіалізм», нав'язування західних цінностей, смаків, образу життя тощо. По-друге, виявляється суперечлива співвідносність нової глобальної культури часового «культурного громадянства», що грунтується на національній ідентичності, традиціях, ментальності і т. п. Історично таке громадянство формувалося на національно-державній основі збереженням культурних зразків, національно-культурних ідентифікаторів, що завжди вважалося фундаментальною засадою існування держави.

Аналітики цієї проблематики завжди наголошували, що «культурне громадянство» належить до невід’ємних прав людини. Воно реалізується через унікальний соціальний досвід, котрий склався у рамках даної культури. У цьому сенсі важливим $є$ використання «систем витлумачення», які дозволяють збагнути і зв'язати індивідуальне із всезагальним (як зазначав Ч. Р. Міллз, «біографію з історією»), що виступає засадничим принципом соціології. Подібну роль відіграють концепти «культурних кодів», «габітусів», ціннісносмислових орієнтацій та ін. соціокультурних засобів, за допомогою яких людина сприймає і пояснює оточуючий світ. Тобто постає проблема як поєднати i гармонізувати ліберально-комунітаристські концепції полікультурності 3 потребами «культурного громадянства», національно-культурної специфікації, що випливає з конкретно-історичних особливостей. 
У сучасному світі борються дві тенденції:

- культурної глобалізації та полікультурної уніфікації соціальних спільнот, змішування у постмодерній плюральності національно-культурних ідентифікаторів і космополітичної «рівності різного» тощо. У наші дні спостерігається прискорене поширення схожих способів мислення, потужний плин уніфікованих образів і символів, зірок та ідолів поп-мистецтва, спорту, моди, шоу-бізнеса... Усі вони створюють характерні риси єдиного нового часу:

- формування нових ідентичностей (групових, стратових на основі стилів життя, культурно-дозвіллєвих уподобань тощо), що втілилися в концепціях «нового трайболізму» (нової племінної окремішності), підкреслення глокальності, відмінності, інакшості, партикулярності.

Глобальні культурні плини контрастують 3 тенденціями і традиційними інституціями на регіональних, локальних рівнях та все ж вони складаються у певні загальні тренди. Вони проявляються там, де ще донедавна про них не могло й бути мови.

Наприклад, прихильниці феміністського руху виступають за права жінок уже в країнах мусульманського світу, а поширеність гей-спільнот перестали бути ознакою «деградації» тільки Західного світу (масові демонстрації на захист сексуальних меншин в Індії, трансвестити в Таїланді як неодмінна складова туристичної індустрії і т. п.)

У різних країнах ці тренди актуалізуються по-різному, вони розведені в часі, але вони мають місце.

Історичні кроки полікультурності. Трансцивілізаційні культурні плини мають глибокі історичні коріння, тоді як державна національно-культурна ідентичність сформувалася значно пізніше. Хоча культурна глобалізація $\epsilon$ феноменом нашого часу i, як зазначають дослідники цього процесу: «не існує історичних аналогів глобалізації та масштабів культурних взаємодій на базі сучасних засобів телекомунікації, трансляції та транспортних інфраструктур» [1, с. 385], культурні взаємовпливи, запозичення й обміни існували завжди.

Передусім, слід відзначити «культурну дифузію» - взаємопроникнення культурних зразків і продуктів сусідніх спільнот. Кордони культурних соціумів часто не співпадали з державними. Так, у поселеннях по різні боки державного кордону люди жили дуже схожим життям, 3 подібними звичаями, смаками, поглядами. Це як 3 мовним розмежуванням, сусіди практикують певне змішання мов, «суржик». Така «мовна дифузія» сприяє кращому взаєморозумінню. Це, до речі, є типовим для усіх прикордонних регіонів України.

Характерним $є$ переймання, певною мірою, звичаїв, смаків, навіть зовнішнього вигляду сусідів. Запорізьки козаки носили яскраві шаровари (як у турецьких яничар, степових вершників) та жупани (як у поляків, мешканців лісостепових зон). Тобто подібність вигляду зумовлювалася схожими природньо-кліматичними умовами і типом діяльності. 
Культурні взаємовпливи розвивалися слідом за розвитком шляхів сполучення між різними соціумами. Прадавні люди селилися вздовж річок або берегами морів, котрі слугували з'єднуючими магістралями. Саме 3 розквітом мореплавства пов'язані перші відомі нам успіхи культурних збагачень різних ареалів людності. Кращим чином це ілюструється на прикладах запозичень кулінарних зразків i продуктів. Кулінарія як певний етно-національний ідентифікатор водночас наочно демонструє приклади культурного взаємопроникнення.

Італійський мандрівник Марко Поло, який відкрив Заходу стародавній Китай, привіз звідси приготування локшиною, згодом вона стала національною ознакою італійської кухні у вигляді «пасти», а італійців іноді глузливо називають «макаронниками». 3 іншої сторони світу до Європи припливли продукти, що стали головною їжею для багатьох країн. Після відкриття Америки Христофором Колумбом на європейських теренах поширилися завезені картопля і кукурудза. Спочатку ірландців стали називати «картоплеїдами», потім Німеччина, Польща, Білорусь та й північ України стали іменувати картоплю «другим хлібом», хоча в харчовому раціоні вона посіла перше місце. Схоже сталося 3 кукурудзою, але вже на півдні Європи. Відтоді мамалига (кукурудзяна каша) стала ознакою Румунії, Болгарії, півдня України (Бессарабіі). Більше того, важко уявити сучасних європейців без кави і чаю, хоча кілька століть тому більшість 3 них і гадки не мали про ці напої. Отже, продукти i способи їх вживання $є$ яскравим прикладом культурного взаємозбагачення. 3 сучасним розвитком світової транспортної інфраструктури, міждержавної, транснаціональної мобільності ця тенденція посилюється.

Роль потужного чинника культурної глобалізації відіграло географічне поширення світових релігій. За ним неминуче слідувало поширення культурних впливів. Найбільш показовим прикладом є глобалізуюча місія християнства. Його серцевиною була експансія єдиного морального кодексу, що пов’язувався iз можливостю спасіння для усіх. Також поширення священних текстів та латини як мови міжнаціонального церковного спілкування, розвій писемності тощо сприяли міжкультурним зв'язкам прихильників спільних вірувань i впровадженню відповідних зразків поведінки. Розвиток інституціолізованої клерикальної ієрархії дав змогу зміцнювати культурні відносини між раніш роз'єднаними суспільствами. Як зазначають дослідники глобальних трансформацій, «ці процеси культурної глобалізації відбувалися повільно, потребуючи десятиліть на їх започаткування і століть на практичне втілення» [2, с.391]. Хоча культурний рівень і уподобання кліриків та еліти рідка збігалися з громадою віруючих, усе ж культурні надбання церкви справляли значний вплив на «формування відчуття міжкультурної ідентичності й лояльності, а також спроможністю створювати потужні теологічні та правові інфраструктури суспільства» [2, с. 392]. Прищеплення гуманістичних цінностей, 
миролюбства і толерантності супроводжувалося між іншим також поширенням певних естетичних стандартів: музична складова церковної служби, хоровий спів (те, що згодом стало означатися як класична музика), церковна архітектура, живопис... 3'явилися там, де вони раніше ніколи не були, на теренах Південної Америки, Африки, Азії, долучивши чисельні народи до загального культурного розвитку людності.

Подібну роль відігравали секулярні ідеології 3 кінця ХУІІІ ст. Поширення світобачення на основі морально-політичної філософії європейського Просвітництва претендувало на універсальне використання й вийшло за кордони свого формування. Ідеї, принципи, настанови лібералізму, соціалізму та сайентизму (наукового світогляду) переможною хвилею поширювалися по нашій планеті. Тобто мали глобальний характер і справляли глобалізуючий вплив.

Зокрема риторика та практики соціалістичного перевлаштування світу, хоча й виникли на грунті критичного аналізу капіталістичної індустріалізації Європи ХІХ ст., класових конфліктів, філософського осмислення соціальної розшарування у цій частині світу, знаходили масову підтримку у відсталих регіонах світового господарства, де ще не відбувалася капіталістична модернізація. Ця ідеологія зазнавала багатьох модифікацій у процесі поширення в Азії, Латинській Америці чи Африці, проте форми політичного врядування, утопічні комуністичні ідеали мали універсальний характер. Програми та гасла, а, передусім дії «єврокомуністів» і «червоних кхмерів», суттєво відрізнялися та світоглядні підвалини залишалися спільними. 3 часом, до XXI ст., їх модернізаційний потенціал вичерпався i поступився ідеології західного лібералізму як системі політичних цінностей, приписів ринкової економіки, громадянських прав і свобод.

Транснаціональні ідеології ліберального демократизму, технократизму, сайентизму доби модерну були принципово секулярними і претендували на універсальне застосування. Нестримний науково-технічний розвиток XX ст., що отримав назву науково-технічної революції, супроводжувався певними змінами способів мислення, морально-політичних цінностей і мистецьких уподобань. Світовий капіталістичний ринок, світова наука, освітні технології неминуче породжували відповідні універсальні культурні орієнтації та практики.

Виникнення імперій, колонізація не тільки як форма політичної глобалізації, а й як культурної інтеграції територій, де проживали різні народи, теж були знаряддям культурних впливів і взаємодії. Проблеми політичної влади i економічного використання на цих територіях розв'язувалися не тільки застосуванням засобів насильства, а й культурними чинниками. Створення культурних інфраструктур були складовою стратегії панування. Крім цього, імперський центр переймався формуванням периферійних еліт, які були 
прив'язані рисами спорідненості, політичними переконаннями, релігією i, що найважливіше, культурними стандартами. Військова i політична влада посилювалася продуктами влади культурної.

Водночас процес культурної експансії не був односпрямованим. Відомий вислів, що «слабіючи, цивілізація для свого відродження потребує варварів» вказує на важливість культури привнесеної зарубіжжям для подальшого розвитку.

Показовою є практика Британської імперії у проведенні імперської освітньої політики i розвиненні засобів комунікації між метрополією i провінціями. Запозичувався зміст і форми освіти з обов'язковим використанням англійських підручників та навчальних програм. Домінування у навчанні англійської мови, практика підготовки певної кількості студентів в британських університетах забезпечували функціювання колоніальної адміністрації. Паралельно відбувалося наслідування форм дозвілля, що не мали історичних чи національних коренів на цих територіях. Так, спортом № 1 в Індії став крикет, а у всьому світі - народжений в Англії, футбол.

Відомо, що для владарювання на віддалених територіях в античній Римській імперії будувалися шляхи. Це забезпечувало не тільки поширення владарювання, але й постійний «прихід свіжої крові» 3 провінцій у центр. шляхи - це рух у обох напрямах. У Британській імперії з цією ж метою в XIX ст. розроблялися системи зв'язку, прокладалося підводні кабелі. До кінця століття кабельна комунікаційна мережа поєднала метрополію з Індією, Австралією, Південною Африкою. Згодом мережа під поверхнею була замінена мережею над поверхнею за допомогою супутників, настала епоха Інтернету. Розвиток комунікативної інфраструктури визначив швидке поширення продуктів і зразків певної культури, робив їх глобальними.

Певним чином у наш час колишні імперії мають зиск 3 культурної експансії минулого. Наприклад, відзначається, що значна частина медичних працівників у Великобританії емігранти з Індії, вони ж складають чисельний загін ІT фахівців у США, тобто закладені освітні стандарти дають свої плоди.

Важливо наголосити, що колоніальна експансія сприяла розвитку людства в цілому, коли вона сприяла поширенню одних (на той час найрозвинутіших) i не перешкоджанню ін. форм культури. Більше того, якщо цього не відбувалося, як це було в імперіях воїнів-кочівників у євразійських степах, які не спромоглися свої військові переваги закріпити здобутками світового значення в сфері культури, то територіальні завоювання не були тривалими і історично значимими.

Аналізуючи процеси культурної глобалізації не можна оминути проблему т. зв. «культурного імперіалізму», під яким розуміється нав'язування форм світобачення, мистецьких продуктів, образу життя, духовних цінностей Заходу усій «решті світу». Тут, думається, треба розділяти два малоповязані 
процеси: розповсюдження маскульту глобальною індустрією, його «просування», як і будь-якого ринкового продукту, та об'єктивну тенденцію наближення до планетарного споживання культурних товарів. Тобто йдеться про той процес, на який звернув увагу 3. Бауман, що суттєва риса глобалізації iii некерованість, самостійний характер усього, що відбувається у світі культури, іншими словами «відсутність пульту управління» [1, с. 45-46]. Адже ситуація постмодерну зовсім відмінна від тієі, що панувала в часи сподівань реалізації модерного проекту: поширення універсальних знань, загального акціонального порядку у планетарному масштабі тощо. За свідченням аналітиків, глобалізаційні процеси у царині культури є абсолютно непередбачуваними й неумисними, вони не мають відношення до того, чого ми прагнемо, а тільки до того, що з нами відбувається.

Ми можемо говорити про «анонімні сили», що діють на теренах, які існують, як правило, поза нашим осягненням i впливом. Політичного суб'єкта цих процесів виявити ще не вдалося. Разом 3 тим, ми стикаємося із слабкістю традиційних суспільних інститутів, котрі займаються підтриманням соціального порядку, відтворенням цінностно-нормативної основи суспільства. Очевидне безсилля, насамперед, демонструє сучасна держава. За влучною метафорою одного радикального соціолога: «в кабаре глобалізації держава виконує стриптиз, і у кінці вистави на ній залишається лише мінімально необхідне - iї репресивні повноваження». Тобто із засобів впливу залишається тільки насилля, але в XXI ст. - це надто не ефективний засіб.

Отже, якщо відійти від пропагандистських гасел «західного культурного імперіалізму», «американізації», які популярні серед антиглобалістів, то ми не побачимо значного гомогенізуючого (створення однорідного), стандартизуючого ефекту глобальної культури, натомість звертає на себе увагу феномен, що отримав назву «глокалізація». Проте незаперечною є тенденція до формування певного уніфікованого типу культурних практик i культурного споживання зі схожими рисами і характеристиками.

Сучасні форми культурної глобалізації пов'язані, насамперед, iз зростанням інтенсивності i обсягу культурного обміну, глобальними комунікаціями усіх типів та домінуванням у сфері культури індустрії мультинаціональних корпорацій виробників i розповсюджувачів продуктів культури. У наші дні склалися глобальні культурні інфраструктури, передусім, Інтернет, мас-медійна мережа телебачення, радіо, тиражованої музики i кінематографа. Спостерігається монополізація культурного ринку певним колом мультинаціональних корпорацій так чи так асоційованих з «західним способом життя», «західними цінностями» та ліберально-ринковими засадами соціальної організації. Ним підпорядковується маніпулювання символами, контролювання морально-ціннісних установок і зразків, що поширюються індустрією масової культури. 
Однак досі не очевидні соціальні та культурні наслідки впливу комунікативних потоків. Навряд чи можна стверджувати їх умисне спрямування якоюсь «світовою за кулісою». За висновками дослідників цих процесів, транснаціональні корпорації, насамперед, «роблять гроші», аніж створюють центри політичного впливу [1, с. 436], проте очевидно, що хто володіє сучасними комунікативними технологіями, той визначатиме значною мірою їх змістове наповнення. Нинішніми глобальними телекомунікаційними засобами (супутниками зв'язку) переважно володіють країни Свро-Атлантичного регіону, передусім США, Західної Свропи, Японії, а країни пострадянського простору, наприклад, менше $15 \%$, тобто вони розташовані нерівномірно по земній кулі. Найважливішим чинником глобальної культурно-інформаційної системи $\epsilon$ поєднання цифрової телекомунікації, комп'ютерних і медійних технологій. Мультинаціональні культурні корпорації формують глобальний культурний ринок. Їх приблизно 20, більшість базується у США. Відзначимо, що на трьох головних світових культурних ринках: музики, кіно і телебачення домінує продукція США.

Окреме питання - мови комунікації. Мовні компетенції постають ключовими у міжкультурній взаємодії. У наші дні в центрі глобальної мовної системи опинилася англійська мова. Вона стала провідною у науковій, економічній, політичній та ін. сферах, а також це основна мова комп'ютерного світу, шоу-бізнесу тощо. Дослідники відзначають, що понад 80 \% електронної інформації фіксується саме англійською. Вона $є$ мовою світової реклами, масової культури. Англійська є нині мовою глобальної міжкультурної взаємодії, а це не тільки засіб передачі змісту. Це також інструмент потужного впливу.

Як нові (з кін. ХХ ст.) форми та засоби культурної глобалізації позначаються на світовій багатокультурності? Які перспективи у елітарної (високій, класичній) культур за сучасних умов панування комерціоналізованої масової культури, бізнесових комунікативних систем? Ці питання залишаються відкритими і потребують подальшого вивчення, проте певні тренди очевидні.

Насамперед структура сучасної культурної глобалізації поступово змінюється: якщо до часів пізнього модерну культурні впливи спрямовувалися із Заходу до решти іншого світу у вигляді наукових досягнень, технологій, моделей суспільної організації, політичного врядування, врешті культурномистецьких зразків для наслідування, то нині, як відзначають аналітики культурного життя, баланс культурних впливів змістився від Західної Європи до США, а також зі Сходу на Захід (через міграцію, ідеї, вірування, національні страви тощо), наплив ідей та культурних практик із т. зв. «третього світу» в розвинуті суспільства. Отже, виникають нові напрями культурних взаємозв'язків. I головне, з точки зору сучасного культурного дискурсу, світ постає як єдине ціле, країни і народи як одна людська спільнота, котру слід сприймати поза політичних, соціальних, духовних та ін. відмінностей. 
Глобалізація вже не тільки вестернізація, це, на думку Я. Пітерзе, «масштаби та глибина усвідомлення світу як єдиного місця» [3, с. 83-84].

Виклики $і$ проблеми культурної глобалізащії. Сучасна культурна глобалізація виглядає процесом досить суперечливим, амбівалентним (що може мати суперечливі наслідки), яке тягне за собою чимало ускладнень і проблем. Серед них позначимо наступні:

- співвідношення 3 національними культурами: міра прилучення національних культур до світових плинів надто різна: одні визначають його напрям, інші пасивно слідують визначеним фарватером, вимушені наслідувати нав'язуванні культурні зразки і практики. Нерідко це викликає спротив, живить ідеї культурної автономії, «альтерглобалізму», стимулює глокалізацію тощо;

- суперечність потребами в національно-культурній ідентифікації, яка відіграє важливу роль у згуртуванні суспільств, особливо у кризові періоди (таких як нині в Україні). Національно-державна ідентичність спирається саме на специфічні риси, традиції, образи, ментальні особливості, зразки й ідеали художньої творчості тощо, що склалися історично і визначені географічно;

- технологічна залежність i комерційна зумовленість культурної глобалізації, ринкові принципи виробництва, поширення i споживання глобальної культурної продукції. Класичні стандарти високої культури, їі смисли і естетичні засади потопають у хвилях потоку комерціалізованої попкультури. Це контрастує 3 культурними обмінами минулих часів, коли поширювалися, насамперед, зразки елітарної культури;

- споживацько-гедоністичне ставлення до культурних практик на Заході зіштовхується із ідейно-ціннісними засадами не тільки великих цивілізацій минулих часів, а й ін. сучасних соціокультурних типів.

Можна зробити висновок, що ми на порозі розуміння постання «глобального людського становища». Феномен глобальної культури - це об'єктивний процес і неминучий етап розвитку людства, їі варто розглядати як процес прискорення і поглиблення культурних взаємозв'язків, що сприяє збагаченню світової культури, інтенсифікації планетарної взаємопов'язаності. Водночас на цьому шляху неодмінно виникатимуть проблеми i труднощі, яким варто приділити увагу.

\section{Список використаних джерел:}

1. Бауман 3. Глобалізація. Наслідки для людини і суспільства / Зігмунт Бауман ; пер. $з$ англ. І. Андрущенка ; за наук. ред. М. Винницького. Київ: Вид. дім «Києво-Могилянська академія», 2008. - 109 с.

2. Гелд Д. Глобальні трансформації. Політика, економіка, культура / Д. Гелд, Е. МакГрю, Д. Голдблатт, Дж. Перратон ; пер. $з$ англ. Ю. Павленко. Київ: Фенікс, 2003. - 584 с. 
3. Глобальні модерності / за ред. М. Фезерстоуна, С. Леша, Р. Робертсона ; пер. $з$ англ. Т. Цимбала. - Київ: Ніка-Центр, 2008. - 400 с.

\section{References:}

1. Bauman, Z. (2008) Globalization. The Human Consequences. Translated from English by I. Andrushchenko. Kyiv: Publishin House «Kyiv-Mogyla Academy».

2. Held, D., McGrew, A., Goldblatt, D., Perraton, J. (2003) Global Transformations. Politics, Economics and Culture. Entry word and translated from English by Yu. Pavlenko. Kyiv: Feniks.

3. Global Modernities. (2008). M. Featherstone, S.Lash and R.Robertson Eds. Kyiv: Nika-Centre.

(C) Танчер B. B., 2018 